Journal of Strategic Security

Volume 7

Number 4 Volume 7, No. 4, Special Issue

Winter 2014: Future Challenges in Drone

Article 12 Geopolitics

\title{
Fighting to the End: The Pakistan Army's Way of War. By C. Christine Fair. New York, NY: Oxford University Press, 2014.
}

Mark Roberts

Follow this and additional works at: https://digitalcommons.usf.edu/jss

pp. 125-127

\section{Recommended Citation}

Roberts, Mark. "Fighting to the End: The Pakistan Army's Way of War. By C. Christine Fair. New York, NY: Oxford University Press, 2014.." Journal of Strategic Security 7, no. 4 (2014) : 125-127.

DOI: http://dx.doi.org/10.5038/1944-0472.7.4.11

Available at: https://digitalcommons.usf.edu/jss/vol7/iss4/12

This Book Review is brought to you for free and open access by the Open Access Journals at Digital Commons @ University of South Florida. It has been accepted for inclusion in Journal of Strategic Security by an authorized editor of Digital Commons @ University of South Florida. For more information, please contact digitalcommons@usf.edu. 
Fighting to the End: The Pakistan Army's Way of War. By C. Christine Fair. New York, NY: Oxford University Press, 2014. 


\section{Fighting to the End: The Pakistan Army's Way of War. By C. Christine Fair. New York, NY: Oxford University Press, 2014. ISBN 978-0-19-989270-9. Maps. Tables, Figures. Notes. Sources cited. Index. Pp. xv, 347. \$34.95.}

Since Pakistan's creation in the 1947 partition that separated it from India, the country has been a source of instability in the region. The author states this is because Pakistan is driven by a cadre of military officers whose ambitions outstrip their capabilities. Given that Islamabad has fought and lost multiple wars with India and has close ties with multiple terrorist groups, the guiding principles behind Pakistan's strategic and national security decision making processes remain a matter of concern for U.S. policy and strategy makers, as well as counterintelligence and counterterrorism professionals.

C. Christine Fair, Ph.D., is one of the foremost South Asia experts. She's currently an Assistant Professor at the Foreign Service school at Georgetown University and previously served at the RAND Corporation, the United Nations mission in Afghanistan, and the United States Institute of Peace. Her first-hand knowledge of the topic makes the book an essential tome for those following South Asia.

The overarching theme of the book is that the Pakistani Army is responsible for the Lion's share of the country's ills as it drives the country into a seemingly endless spiral of poor choices militarily, economically, diplomatically, and in the arena of public relations. Dr. Fair thoroughly understands the Pakistani national psyche and explains it with extreme clarity. Whereas most countries have an army, she correctly posits that Pakistan is in fact an army that has a country to do its bidding.

The author used Pakistani defense journals, literature, and doctrine as primary her sources for the book. With this insight, she is able to demonstrate authoritatively how military doctrine has shaped the entire national security perspective for Pakistan. According to their own statements, the Pakistan Army is the guardian of the nation's ideology and culture. Her treatment of the Pakistan Army covers the country's sociology, psychology, anthropology, religious trajectory, and military doctrine. Employing such a holistic manner, she deftly explains how Pakistan under the control of its army has been, is, and (absent a change in trajectory) will remain a destabilizing force to its own detriment, as well as that of its neighbors.

When Pakistan and India were rent asunder at the end of the British Empire after WWII, India retained most of the territory, governmental infrastructure, resources, and institutions left in place by the British. Pakistan, birthed in a chaotic environment, had to devise - on the fly - a new national identity, society, 
military, government, infrastructure and culture. Seeking to establish an identity completely distinct from that of its larger and more powerful Indian neighbor, the Pakistan Army took control of the control and assumed an antagonistic stance toward New Delhi, plunging immediately into a war over who would control Kashmir.

The author frames the Pakistan Army's paranoia regarding India and Kashmir as more of an ideological issue than a truly security driven one. Due to the compulsive desire to match India's national capabilities, the generals in Islamabad will continue to pursue reckless courses of action towards New Delhi. The rallying cry has been to pit "Muslim" Pakistan against "Hindu" India, despite significant Sikh, Muslim, and Buddhist populations in India, with the Kashmir card ever at the ready to be played.

Although Kashmir's intrinsic value (or lack thereof) as a piece of land has been endlessly discussed, Pakistan's loss framed its relationship with India - eternal struggle tinged with envy. Even though Pakistan cannot win in a conventional war against India, the army has chosen to engage in guerrilla warfare, proxy warfare, terrorism, low intensity conflict, and, despite repeated losses, full scale war. India has decisively won every war and sees no need to make any concession to Pakistan. Yet the generals in Islamabad still expect New Delhi to yield to their demands, which, counterintuitively, grow after every defeat. Although Pakistan has not gained one iota of traction, it obsessively seeks equality with India. While India has fostered a reasonably successful democratic process with economic expansion, Pakistan has gone completely in the other direction, with multiple military dictatorships and an economy that needs massive infusions from the World Bank and International Monetary Fund to subsist.

The Pakistan Army has aggressively pursued a nuclear program in an effort to seek some modicum of military parity with India, despite withering international sanctions. Due to its support for numerous terrorist groups, Pakistan came very close to being declared a state sponsor of terrorism by the U.S. State Department and later was almost declared an enemy combatant after the 9/11 attacks. The army dominates foreign, defense, economic, religious and domestic policies. Its long-term mismanagement of the country brings to mind Governor Bill Clinton's quip from the 1992 campaign about the meaning of insanity: doing the same thing over and over again and expecting a different result.

As Fair outlines the Pakistan Army's strategic blunders, she suggests that the gap between the national capabilities of Pakistan and India will continue to widen in New Delhi's favor. The longer Islamabad, under the full sway of the Pakistan Army defies the consequences of its actions, the harsher the eventual concussion will be, whether militarily, economically, or diplomatically. The generals in 
Islamabad are willing to suffer endless military defeats to seek an unattainable advantage vis-à-vis New Delhi and improve their position in Kashmir. This mentality leads to an endless spiral of defeat that to the western mind seems irrational.

The Pakistan Army controls the state and every apparatus at its disposal, using state organs for its own ends. One of the top priorities is serving as the guardian and protector of Pakistan's uniquely Islamic identity. Within this paradigm, the struggle with India is framed as a civilizational one, with existential ramifications if Islamabad yields to New Delhi. Viewed through this lens, victory is not cast in military terms per se (as it is unachievable anyway). Victory is not yielding or conceding any point of order to India. This sense of false optimism (or hubris) has led to a country run by a military that is revisionist, delusional, and prone to initiate conflict as a matter of pride.

Dr. Fair's book belongs on the shelf of those interested in U.S. strategy, policy or military affairs in South Asia. It also essential is for those seeking to understand sources of strategic instability in South Asia and how the Pakistan Army's sponsorship of terrorism and warfare will ensure the region remains volatile until Islamabad chooses a more rational path.

Mark Roberts 